\title{
"A Dangerous Man": \\ Lewis Terman and George Stoddard, their Debates on Intelligence Testing, and the Legacy of the Iowa Child Welfare Research Station
}

\section{STEVE MCNuTT}

IN 1886, on a farm south of Indianapolis in Johnson County, Indiana, a traveling salesman of books on phrenology stops for the night. Explaining to the family how phrenologists study the cranium for signs of mental abilities and personality traits, the salesman feels the bumps on the head of each of the Terman family's 14 children. The twelfth, a boy, approaches when called. Red hair parted down the middle, wearing round glasses, Lewis Terman is nine years old. He is overly aware of being different. For one thing, he likes school more than the other boys. Then there are the feelings of physical inferiority he will recall his entire life. And now someone is about to assess his intelligence. As tests go, the stakes are rather high.

The salesman lays his hands on Lewis's head, spreading his fingers out wide to grasp his scalp. His touch is light, at times hovering over Lewis's scalp. Working from Lewis's forehead up to the crown of his head then down to each ear, he issues an occasional "hmm" that to Lewis's ears sounds - positive? Still not speaking, the salesman removes a set of steel calipers from his bag. He pinches skin behind ears still resonant with the scratch

THE ANNALS OF IOWA 72 (Winter 2013). (C) The State Historical Society of Iowa, 2013. 
of a penciled notation. He repeats the process. More notes and numbers follow, then the moment is over and the salesman grabs Lewis's frail shoulders and pronounces to the room that when it comes to this boy's future, he sees "great things."

Lewis's older brother buys a copy of the book, which Lewis finds fascinating into his early teens, and it inspires a lifelong love of reading. On his way to a Ph.D. in psychology he will learn French and German so that he can read works of psychology and philosophy in their original languages. As a professor of psychology at Stanford University he will become known as one of the world's foremost experts on intelligence testing and a vigorous advocate of the idea of intelligence as an unchanging, unitary trait based almost entirely on heredity. ${ }^{1}$

On numerous occasions toward the end of his career, Terman will write about the visit, saying it affirmed his own intelligence and gave him confidence that he could do "great things." 2 Even though he later dismissed phrenology as pseudo-science, in that moment he had felt the hand of destiny, and it resonated with Terman, a man who would spend his career first advocating, then defending, the idea that environment-society - had little effect on the core intelligence of human beings and, by extension, on the ultimate direction of their lives. The depth of his resistance to the role of environment becomes clear in the story

1. The description of this event and its meaning for Terman's life has been constructed based on several different sources. Of the many references to this story in which he interprets the event Terman writes, "Perhaps I remember the incident so well for the reason that when it came my turn to be examined he predicted great things of me. I think the prediction probably added a little to my self-confidence and caused me to strive for a more ambitious goal than I might otherwise have set. At any rate, I was greatly impressed and for several years thereafter was much interested in phrenology. As my older brother bought a copy of the book, I finally became familiar with its contents and believed in phrenology until I was fourteen or fifteen years old. This was my introduction to the science of individual differences and the diagnosis of personality." "Autobiography of Lewis M. Terman," first published in Carl Murchison, ed., History of Psychology in Autobiography, vol. 2 (Worcester, MA, 1930), 297-331. The event is referenced in two biographies of Terman: Henry L. Minton, Lewis M. Terman: Pioneer in Psychological Testing (New York, 1988), 47; and Edwin G. Boring, Lewis Madison Terman, January 15, 1877-December 21, 1956, Biographical Memoirs (National Academy of Sciences) vol. 33 (New York, 1959), 418. The description of "reading the bumps" is based on the common practices of phrenologists.

2. “Autobiography of Lewis M. Terman," 297-331. 


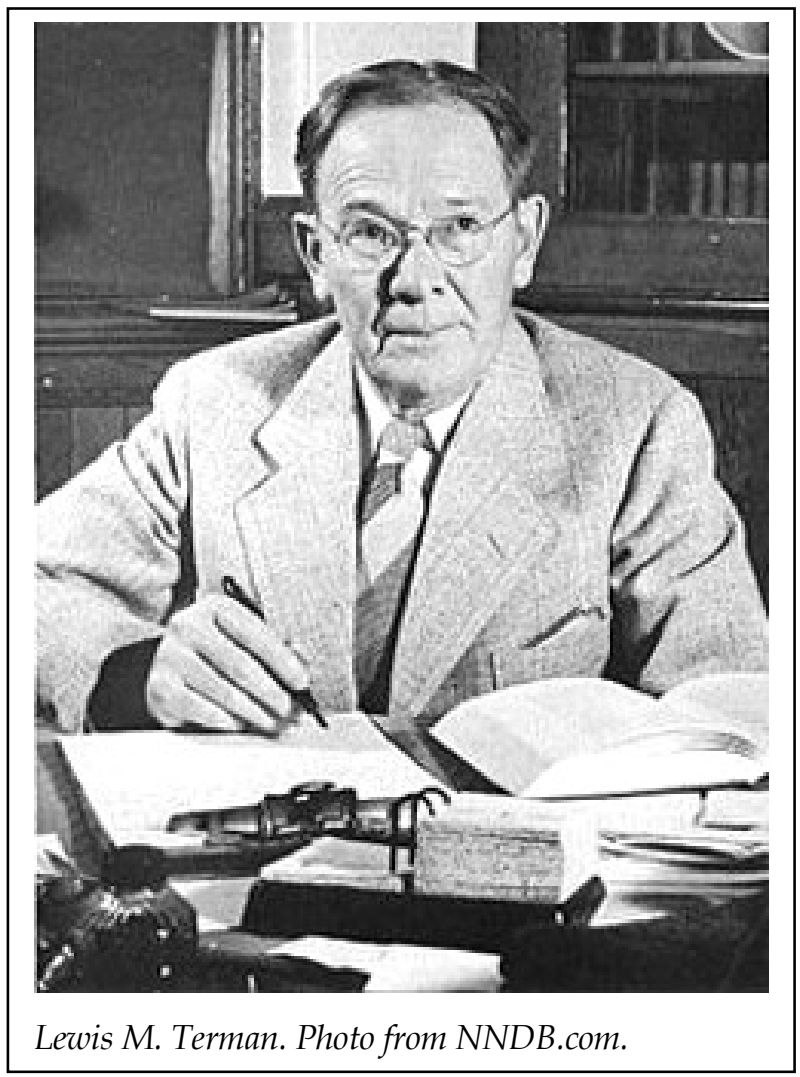

of his debates with researchers from the "Iowa school" of psychology as defined by the work of the Iowa Child Welfare Research Station (ICWRS), a state-funded project to research child development. Terman's hereditarian views on intelligence are often portrayed as softening later in life, but that does not appear to be so when his views are examined within the context of his debates with the director of the ICWRS, George Stoddard, a person Terman would deem a "dangerous man."

BORN IN 1897, twenty years after Terman, in the coal-mining town of Carbondale, Pennsylvania, Stoddard was the fourth of five children. As an adult, he would defend the interactionist position, the argument that environment and intelligence influence one another. Of his own environment, he remembered his 
father as the dominant presence in the family, a person who worked as a wrecking-crew foreman for the railroad, eventually giving that up to sell insurance. As one of the youngest children in his family, Stoddard remembered feeling "ornamental"; his older sisters would dress him up as a proper boy and dote upon him. Initially, he disliked school so much that he left during recess of his first day in first grade. At home, his mother advised that he would probably miss something important if he did not go back, but if he wanted to stay he could, since she needed help with chores around the house. To school he returned. In some ways, he never left. ${ }^{3}$

Raised Methodist, he lived in a world of rules and restrictions - no smoking, drinking, card playing, or reading of comic books. Sundays were spent indoors; he recalled watching from the window with envy as the Catholic kids played baseball outside. Economically, the town was in decline. Stoddard described life in Carbondale as "drab," the municipal park "fenced in like a cemetery and just as lifeless," the public library "puny and repulsive" - but life was made tolerable by the boy's close proximity to woods, hills, lakes, and kind neighbors. ${ }^{4}$

Age 12 marked the onset of Stoddard's skepticism toward religion. He found "intolerable the wooden answers to burning questions." With a group of friends he "literally stalked out of the little church school never to return." At about the same time, he was first exposed to "communal violence linked to irrational dogma" when he witnessed a group of men throwing rocks and bricks through the windows of a Baptist church. The male worshipers confronted the other men, but the police did not respond. Stoddard later learned that the police force was largely Catholic and the mob was made up of Catholics trying to disrupt the sermon of a visiting preacher known for anti-Catholic messages. From this event, Stoddard concluded that religion was a source of violence and division. ${ }^{5}$

Becoming a nominal Unitarian later in life, he sought a spiritual path, reaching beyond "work and play." In Unitarianism

3. George Stoddard, The Pursuit of Education (New York, 1981), 7-8.

4. Ibid., 9 .

5. Ibid., 12. 


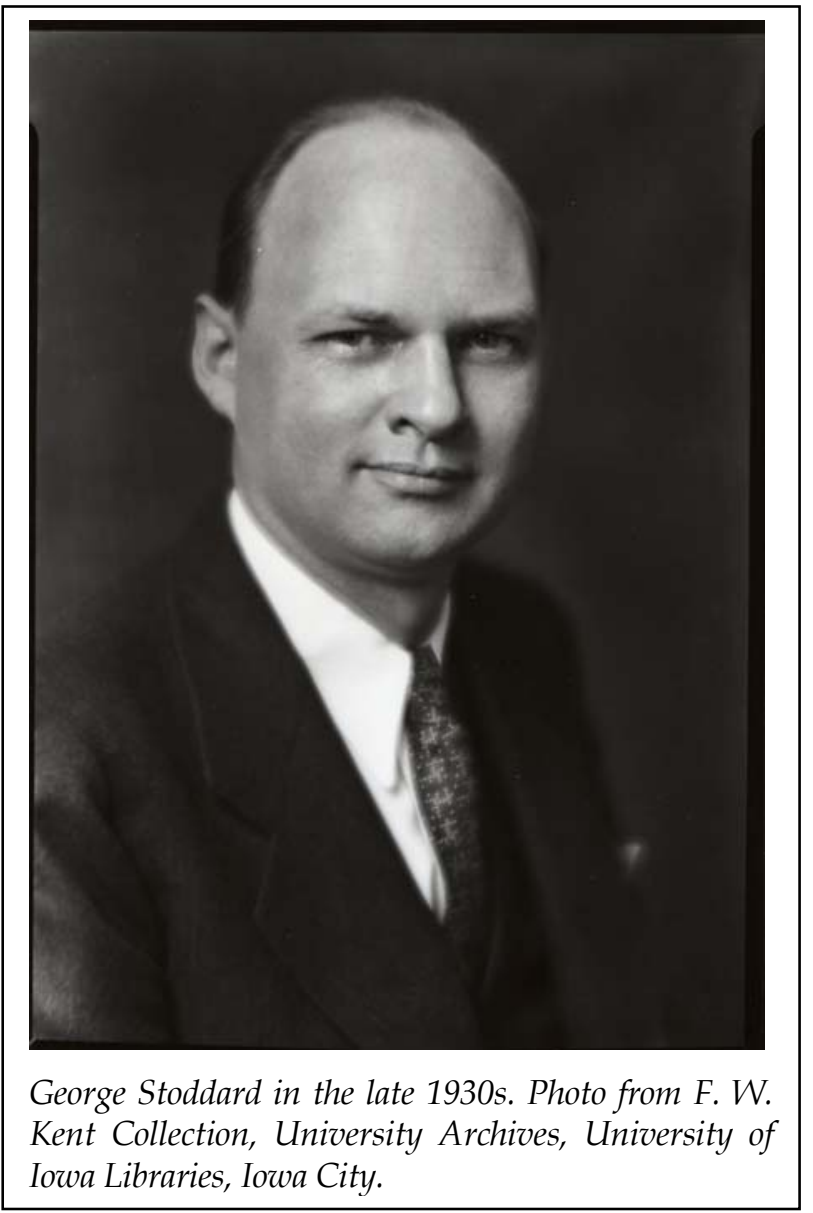

he found "a liberalizing religion devoid of cant." 6 His early doubts about religion appear as a critical moment that would eventually lead to his criticism of hereditarian views on intelligence and intelligence testing. In his view, hereditarian thinking and religion were similar: Humans had created God in the same way they created concepts of an all-encompassing heredity in which everything was explained and dictated by genetics. ${ }^{7}$

One other experience may have influenced Stoddard's hesitance to explain life through genetics. While he was still a child,

6. Ibid., 320-25.

7. Ibid., 329-33. 
his eldest brother, Arthur, had left home and lived a hard but adventurous life including travel at sea. Arthur returned home at age 30 with what Stoddard described as an incurable liver illness. He died the day before Stoddard's high school commencement, at which Stoddard, as class salutatorian, gave the opening address. He was coming to its conclusion when "there swam before my eyes a corpse-my brother's rosy-cheeked face magically restored to life and intimacy! How long this fantasy lasted I do not know; no one ever mentioned a hesitation in my delivery. But I remember tightly shutting my eyes and, behold, the image floated away and the closing words of my speech came back to me." 8

INTERACTIONISTS like Stoddard argued that the "natural" aspect of the hereditarian argument provided a rationale for justifying inequality. The story behind the mechanism used to do so begins with the creation of the Binet-Simon Scale in 1904. Alfred Binet, director of the Sorbonne's Laboratory of Experimental Psychology in France, and Theodore Simon grounded their work on that of Sir Francis Galton, the founder of the eugenics movement and Charles Darwin's cousin. The BinetSimon Scale was designed at the request of the minister of public instruction in France to identify "subnormal" children "unsuited" for a mainstream, mandatory schooling environment. The result was the world's first test for intelligence. The test attempted to set standards for age-appropriate tasks requiring abilities not taught in school such as judgment, memory, attention, and problem-solving skills. Yet Binet warned against the test's potential for misuse, calling the notion that intelligence could not be improved a "brutal pessimism." Nor did he agree that the term intelligence quotient was capable of representing intelligence with a single number - the idea that drove the creation of "IQ." 9

The idea that a single number could describe someone's intelligence was the work of the German psychologist Wilhelm Stern. He proposed the concept of "mental age," from which he

8. Ibid., 9 .

9. Theta H. Wolf, Alfred Binet (Chicago, 1973), 172, 178. 
claimed to derive a person's "intelligence quotient" (IQ), a leap in reasoning that Binet's colleague Simon called la trahison - the betrayal, or treachery - for its redefinition of the test's results. Neither he nor Binet accepted the equation behind IQ as mathematically valid or used the term, preferring the intentionally vague term "mental level."10 Binet was confident that he and Simon had authored a test that could help to identify children of below-average intelligence, but he did not believe that the test measured the "richness of intelligence," a concept he refused to define or hypothesize about. ${ }^{11}$ Even though intelligence testing was a French creation, it became much more popular in the United States than in France. The French preferred to rely on the judgment of experts evaluating individuals rather than cede that role to a test. ${ }^{12}$

After the psychologist and eugenicist Henry Goddard initially translated and introduced the Binet-Simon Scale to the United States, Lewis Terman revised, expanded, and marketed the test as well as the concept of IQ. He produced its numerical scale for assessing intelligence by using the test to determine a "mental age" score. That score was then divided by the testtaker's chronological age and multiplied by 100.

After producing a few relatively short versions of the test, in 1916 Terman published The Measurement of Intelligence, an expanded version that would launch the testing industry. Part test and part manifesto, the book employs every racial stereotype of the era alongside a distrust of teachers, a preference for tests, and a belief in intelligence as a "unitary," that is, a single, uniform trait. ${ }^{13}$ In an inspired move toward co-opting Binet's work and reputation, Terman dedicated the book to his memory. By then, Binet had died, and his qualifications about his test were soon forgotten, especially in the United States.

In Terman's explanation of what would become known as the Stanford-Binet IQ Test, we hear a voice that is unequivocal in its worldview.

10. Ibid., 195, 203.

11. Ibid., 215.

12. John Carson, The Measure of Merit: Talents, Intelligence, and Inequality in the French and American Republics, 1750-1940 (Princeton, NJ, 2007), 5.

13. Minton, Lewis M. Terman, 46-48. 
Among laboring men and servant girls there are thousands like them [feebleminded individuals]. They are the world's "hewers of wood and drawers of water." And yet, as far as intelligence is concerned, the tests have told the truth. . . . No amount of school instruction will ever make them intelligent voters or capable citizens in the true sense of the word....

The fact that one meets this type with such extraordinary frequency among Indians, Mexicans, and negroes suggests quite forcibly that the whole question of racial differences in mental traits will have to be taken up anew and by experimental methods....

Children of this group should be segregated in special classes and be given instruction which is concrete and practical. They cannot master abstractions, but they can often be made efficient workers, able to look out for themselves. There is no possibility at present of convincing society that they should not be allowed to reproduce, although from a eugenic point of view they constitute a grave problem because of their unusually prolific breeding. ${ }^{14}$

POPULAR EXCITEMENT about the potential uses of intelligence testing was a product of circumstance. Fears of increasing immigration drove some to want to verify who was worthy of citizenship. It was anticipated that future population and economic growth would rely on immigration. Confronted with a perceived need to rely on the labor of potentially "substandard" people, the hereditarians believed that the country needed to preserve traditional power structures and avenues to privilege for those who were defined as white Americans, in case they became a minority. Intelligence tests painted a gloss of objectivity on the idea of a meritocracy, and the imported Binet-Simon Scale was retrofitted to advance the hereditarians' goal. ${ }^{15}$

Growing public interest in and acceptance of the viability of the IQ test was a product of World War I. In the latter stages of the war, the U.S. army began to use a version of the IQ test as a means of sorting recruits. After initial resistance, many politicians and high-ranking military leaders accepted the test, while

14. Lewis Terman, The Measurement of Intelligence: An Explanation of and Complete Guide for the Use of the Stanford Revision and Extension of The Binet-Simon Intelligence Scale (New York, 1916), 91-92.

15. A. J. Jaffe, "Population Growth and Fertility Trends in the United States," Eugenical News 2 (1941), 26, 64-68. 
seasoned officers resisted, and many simply refused to take it. In practice, the test was poorly administered in large halls where it was difficult for test-takers to hear instructions. As a result, a large percentage of soldiers scored as mentally handicapped. The army objected that, instead of measuring intelligence, the test measured familiarity with a question's content as well as speed. Nonetheless, the results would be publicized in the popular press after the war as evidence of a crumbling society, feeding debates about the influence of immigrants, people of non-Western European backgrounds, and Communists. Still, the IQ test had gained a foothold as a tool for large-scale institutional use. ${ }^{16}$

As the IQ test's popularity increased, so did its number of detractors, who noted several problems related to the army's questions about what the test was testing. Inventiveness was not rewarded, and some answers were simply arbitrary and confusing. But the main problem was that the questions were highly subjective. The range of acceptable answers was narrow because the norms had been established by administering the test solely to white, middle-class children and using their experience as the basis for defining what qualified as a correct answer. Test questions commonly used illustrations of white, middle-class life, then asked test-takers to interpret the scenes. ${ }^{17}$ Questions that did not rely on illustrations presented similar problems. The following question, which Terman added to Binet's original test, exemplifies how IQ tests used questions that read like riddles to evaluate a test-taker's abstract reasoning skills:

An Indian who had come to town for the first time in his life saw a white man riding along the street. As the white man rode by, the Indian said - "The white man is lazy; he walks sitting down." What was the white man on that caused the Indian to say, "He walks sitting down." 18

The answer identified as correct was "bicycle" because the Indian describes the white man as "walking," meaning he must be observing up-and-down leg movement. The most common incorrect answer was "horse," which Terman deemed incorrect

16. Carson, The Measure of Merit, 208-10.

17. George Stoddard, The Meaning of Intelligence (New York, 1943), 103.

18. Stephen Jay Gould, The Mismeasure of Man (New York, 1996), 206. 
because a person's legs do not go up and down while riding a horse. In addition, the test-taker was supposed to read the question as inferring that the Indian was unfamiliar with the object, and presumably he would not be unfamiliar with a horse.

Critics of this question and others like it observed that while it claimed to test abstract reasoning, it actually measured conformity and familiarity with social norms. The question really tested the degree to which a person viewed an Indian as a primitive unfamiliar with modern technology; it measured the testtaker's ability to think abstractly not as an Indian thinks but as Terman thought of Indians, that is, to share Terman's perception of the Indian's behavior, psychology, and intellect.

Writing in The New Republic starting in 1922, the journalist Walter Lippmann and educational reformer John Dewey levied a series of related criticisms at the intelligence-testing community. They identified methodological problems with intelligence tests and warned of the potential outcome for a society that relied on them. Lippmann wrote six articles criticizing Terman's interpretation of the data, concluding that Terman could not demonstrate that he was testing what he claimed to be testing. The IQ test, feared Lippmann, amounted to an assault on democratic ideals of self-determination likely to evolve into an "intellectual caste system in which the task of education had given way to the doctrine of predestination and infant damnation." 19 Dewey added that the IQ's "abstract and universal idea of superiority and inferiority is an absurdity." 20

Terman responded in a 3,400-word article in The New Republic. Using a dismissive and condescending tone, he ignored Lippmann's questions and, as became his habit, mischaracterized the criticism as asserting that no differences of any kind existed between individuals. Comparing Lippmann's critique of intelligence testing to William Jennings Bryan's attack on evolution, he sarcastically agreed with Lippmann, saying it was "high time we penetrated the wiles of this crafty cult." He then expressed false distress as to the worldwide popularity of his

19. Walter Lippmann, "The Mental Age of Americans," The New Republic, 10/25/1922, 213-15; 11/1/1922, 246-48; 11/8/1922, 275-77; 11/15/1922, 29798; 11/22/1922, 328-30; 11/19/1922, 9-11.

20. Minton, Lewis M. Terman, 105. 
views on intelligence. Referring to Germany as being "taken in" by such views, he wrote that if "the German people don't wake up they will soon find themselves in the grip of a super-junker [landed nobility] caste that will out-junker anything Prussia ever turned loose." Lippmann, stated Terman, was not intelligent enough to understand intelligence testing. Science, he concluded, should be left to the scientists. ${ }^{21}$

The reaction was typical of Terman's response to those who questioned the validity of his tests. In a variety of publications and speeches he stated that the answer to the questions they raised was too obvious to merit an answer. Doubts about social stratification and its roots received similarly superficial treatment in The Measurement of Intelligence. "Common observation," he wrote, "would itself suggest that the social class to which the family belongs depends less on chance than on the parents' native qualities of intellect and character." 22 Such statements portray science as a matter of faith; when it suited him, "common observation" was all the proof he required.

Terman's selective use of evidence is reflected in the explanation he offered as a way to understand his own life. Aside from the chance encounter with phrenology that sparked his passion for reading, growing up on the farm offered Terman little evidence that his success was based in anything but heredity. He could see nothing about his early life that helped prepare him for his future success. He was a sickly child who, at various points in his life, struggled with tuberculosis. He never enjoyed sports or other physical activities. Instead, he developed academic interests along with a competitive and tireless work ethic. Terman concluded that his forebears' intelligence had never presented itself because they had lacked access to means of (academic) expression. ${ }^{23}$ Terman also attributed his son's election to the

21. Minton, Lewis M. Terman, 102-4; Lewis M. Terman, “The Great Conspiracy, or the Impulse Imperious of Intelligence Testers, Psychoanalyzed and Exposed by Mr. Lippmann," The New Republic, 12/27/1922, 116-20.

22. Terman, The Measurement of Intelligence, 115.

23. As his biographers have noted, Terman himself benefited from private loans facilitating his education, from undergraduate through doctoral work, and he also had a spouse who was supportive of his ambitions. Boring, Lewis Madison Terman, 415-61. 
National Academy of Sciences to heredity, though neither his daughter nor any of his siblings achieved such notoriety. ${ }^{24}$ In using selective individuals from his family as evidence of the inevitable consequences of heredity, Terman disregarded family members who, while biologically related, did not share the same traits as he did. That allowed him to make one of the more nuanced missteps behind hereditarian notions of intelligence: the assertion that group-based classifications can be used to predict with certainty who we become as individuals.

NEITHER STODDARD NOR TERMAN came from extraordinary wealth. Both received an exceptionally high level of formal education for a period when only approximately 10 percent of high school graduates attended college. Politically, both were liberal Democrats. Stoddard was 11 years younger and a true New Deal Democrat, but Stoddard's upbringing was more privileged than Terman's and allowed for more diversions, which, by accident rather than design, became vital to his views on intelligence. After working at a bank after graduation from high school, Stoddard enrolled at Penn State. He tried industrial chemical engineering, left for a short stint in the army, then returned to Penn State and mathematics, physics, and other hard sciences. None held his interest, and he repeatedly found himself in the humanities, ultimately settling on a degree in education, followed, in 1923, by a year of graduate study in psychology at the University of Paris with Theodore Simon. 25

Stoddard had initially intended to study in Germany. The field of modern psychology dates to 1879, when the first formal laboratory of experimental psychology was founded at the Uni-

24. Later in his career, Terman modifed his initial view that men were, on average, more intelligent than women. His biographer speculated as to how his earlier notion may have affected his treatment and expectations of his own children, who were routinely given intelligence tests in their youth (as were his grandchildren). Terman devoted much of his parenting energy to his son, Frederick; he had a distant relationship with his daughter, Anna. Frederick would echo his father's accomplishments; he became a professor of engineering at Stanford and, like his father, was elected to the National Academy of Sciences. Anna, as expected, married and became a mother, living close to home for the rest of her life. Minton, Lewis M. Terman, 257-59.

25. Stoddard, The Pursuit of Education, 321-23. 
versity of Leipzig by Wilhelm Wundt. (Wundt would train the American psychologist G. Stanley Hall, under whom Lewis Terman studied). Leipzig, then, was the obvious destination for Stoddard. But German psychologists, motivated by Germany's slow recovery from World War I and Hitler's growing power, left for the United States, where many of their former students were teaching. If Stoddard wanted to study with German psychologists, there was no need to leave the United States, and he had already been exposed to many of their ideas; France, by contrast, was politically stable, and its theorists were more appealing to Stoddard, who described them as intuitive and brilliant. ${ }^{26}$

In Paris, Stoddard encountered Binet's original work directly. Stateside U.S. students in educational psychology, who knew about Binet's scale, had less contact with the reasoning behind its creation and its authors' own caveats about the test and its imperfections. That made it easier for students to become entranced by the seemingly unassailable exactitude offered by the test's results and thus to come to see evidence of biological determinism as the chief engineer of intelligence. ${ }^{27}$

After a year of study in France, Stoddard accepted a research assistantship at the University of Iowa. There, he went to work for G. M. Ruch, a professor who had studied at Stanford. Their task was testing the general intelligence of incoming freshmen, but they struggled to find correlations between their results and students' level of success. ${ }^{28}$

Stoddard's dissertation, "Iowa Placement Examinations" (1925) attempted to solve the problem of student assessment. Built on the idea that designing a generalized test able to encapsulate a person's capacity for building knowledge was a practical impossibility, Stoddard's solution was two tests: one testing aptitude for learning, the other testing what the person already knew. ${ }^{29}$ Those tests were more successful at predicting student

26. Ibid., 327.

27. Ibid., 329.

28. Ibid., 39. Stoddard would also coauthor a book with Ruch on testing high school students, for which Terman wrote a long introduction. Through Ruch, Terman offered Stoddard a fellowship if he would transfer to Stanford. It was an offer Iowa could not match, but Stoddard elected to stay in Iowa City.

29. Ibid., 39. 
achievement and were eventually adopted by the university. He went on to write a series of tests used throughout the United States as placement exams.

By this stage of his education, however, Stoddard had enough experience with testing to understand its weaknesses. He never developed a faith in a particular test's ability to quantify an ultimate truth. His awareness of the University of Iowa's poor initial experience with intelligence tests and his own authorship of other tests would influence how he viewed the rapid adoption of standardized tests of all kinds at all educational levels by those who saw them as tools for bringing order to society.

STODDARD'S GRADUATE STUDIES had begun two years after the founding of the Iowa Child Welfare Research Station (ICWRS) in 1917. ${ }^{30}$ Achieving funding for the research station took years of wrangling with the state legislature; psychology was still a relatively new field, and the idea of studying children invited suspicion. Public opinion was swayed thanks in part to newspaper editorials pointing out that the state spent more time and money studying its hogs than its children. As an example of what happens when children are not given adequate educational opportunities, newspaper editors pointed to the recent rejection of "thousands" of "normal" Iowa men as unfit for military service. ${ }^{31}$ With victory in the battle for funding, the university turned a series of houses into offices, a preschool nursery, and a library - all dedicated to studying the "normal" child. Lewis Terman was offered the directorship of the program. This story would have had developed very differently had he not turned it down. ${ }^{32}$

In Before Head Start, historian Hamilton Cravens describes the ICWRS as possibly the first research institute in the world and certainly in the United States dedicated solely to conducting original scientific research on the development of "normal"

30. Pioneering in Child Welfare: A History of the Iowa Child Welfare Research Station 1917-1933 (Iowa City, 1933), 25.

31. The U of I's Institute of Child Behavior Celebrates Its First 50 Years (Iowa City, 1968).

32. Hamilton Cravens, Before Head Start: The Iowa Station and America's Children (Chapel Hill, NC, 1993), 104. 
children, and the first with a preschool nursery for research purposes. ${ }^{3}$ Throughout its first decade, the ICWRS had limited funds and a small staff, but by 1928 increased state and grant funding allowed it to achieve national prominence. Shortly thereafter, its first director, Bird T. Baldwin, died suddenly.

That same year the U.S. Supreme Court affirmed the constitutionality of laws mandating the sterilization of mentally handicapped people, along with laws requiring all citizens to have racial designations listed at birth, thus codifying the "one-drop rule." The sterilization laws were derived from the 1922 publication of Harry Laughlin's Model Eugenical Sterilization Law, which relied on the claims of hereditarians. ${ }^{34}$

In that context George Stoddard took a job he did not want. Stoddard liked to joke that the university president chose him to succeed Baldwin as director of the ICWRS out of simple desperation. Stoddard had never intended a career as an administrator, but in 1928, three years after completing his doctorate in child psychology, with 15 published research articles and as one of the original authors of the Iowa Placement Tests (which attempted to assess learning by grade level), he agreed to a oneyear interim term as director of the ICWRS. ${ }^{35}$ Hired as an interim director, he did not behave as one. The research station's mission quickly shifted from one originally intent on intervention in critically at-risk families to one focused on studying childhood development in a way never before attempted.

Correspondence from that year demonstrates the reputation Stoddard had developed within the university. The dean of the

33. Ibid., 262. Two other institutes, one at Yale, the other in Detroit at the Merrill-Palmer School, also studied child development. (Noting a detail critical to defending the ICWRS, Stoddard would later point out that Iowa was neither alone, nor the first, to demonstrate gains in IQ scores; the Merrill-Palmer School reported gains by its students in 1925 after the first year of attendance. Stoddard argued that the lack of other studies with similar findings reflected the high quality of the researchers at Iowa. Daily Iowan, 12/29/1939; Cravens, Before Head Start, 97, 101.

34. Claude Moore Health Sciences Library, University of Virginia Health System, "Origins of Eugenics," www.hsl.virginia.edu/historical/eugenics/ 2-origins.cfm. The "one-drop" rule defined as "black" any individual with any African ancestry (or "one drop" of black blood).

35. Cravens, Before Head Start, 106. 


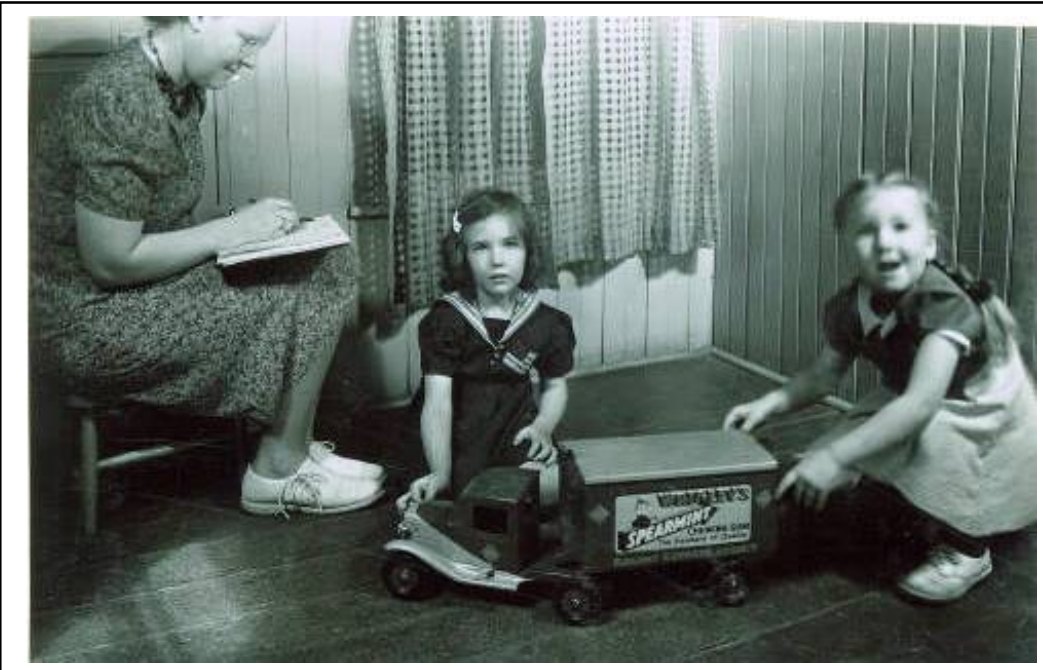

Gertrude E. Chittenden observes children at play in the Iowa Child Welfare Research Station's preschool for her thesis research in 1941. Photo from F. W. Kent Collection, University Archives, University of Iowa.

Graduate College, Carl Seashore, wrote to university president Walter Jessup to "join" in recommending Stoddard's promotion from assistant to associate professor, as his growth had been "rather remarkable." Seashore made it clear that people in Stoddard's field were in high demand; he worried that Stoddard might be tempted to look elsewhere. ${ }^{36}$

Seashore's effort to retain Stoddard was successful. Under Stoddard's leadership, work by ICWRS researchers Beth Wellman, Marie Skodak, Ruth Updegraff, and Howard Skeels repeatedly questioned what IQ was and whether it was, as hereditarians claimed, a fixed, unitary trait. Along with Skeels, Wellman authored numerous Iowa studies. In 1932 she wrote the first of many articles on the effects of schooling on intellect. She questioned whether intelligence was innate. One of the ear-

36. Carl E. Seashore to President Jessup, 2/22/1928, Child Welfare Box, University of Iowa Archives, University of Iowa Libraries, Iowa City. The esteem was mutual. Stoddard wrote that Seashore was 40 years ahead of his time in placing performance in the arts and literature on equal footing with other studies. Stoddard, Pursuit of Education, 48. In 1936 Stoddard would succeed Seashore as head of the Department of Psychology and dean of the Graduate College. 
lier ICWRS studies had found a greater increase in student IQ scores between the fall and spring semesters, when school was in session, than when it was not in session, implying that improved scores relied at least partly on education. ${ }^{37}$ The hereditarians dismissed the findings, saying that the Iowa researchers were not properly trained and did not understand IQ. This began a pattern in which ICWRS research was rejected by others in the intelligence-testing community.

SEVERAL OF THE ICWRS STUDIES took place at the Iowa Soldiers' Orphans' Home in Davenport, Iowa. The lead study was titled, quite transparently, "A Study of Environmental Stimulation: An Orphanage Preschool Project." Its genesis was a problem facing the Orphans' Home and its supervising body, the State Board of Control. After settling a lawsuit by an Iowa couple who learned that their adoptive child was mentally handicapped, the Orphans' Home administrators became concerned about the potential for other parents to adopt a child who might be "feeble-minded." Motivated by the desire to avoid future lawsuits, they contacted Stoddard to help them determine the level of intelligence of the children in their care. ${ }^{38}$

The ICWRS researchers found an orphanage comprising several cottages, each housing 30-35 children of the same sex and younger than six years of age. The largest room in each cottage was 15 square feet. One trained adult and three or four untrained teenaged girls were responsible for the children's care. By necessity, the children lived a rigid, regimented life, isolated from the outside world. Treated as a group with no personal belongings besides a toothbrush (clothing was shared), the children, according to the Iowa researchers, struggled to see themselves as individuals and moved en masse. Many were not toilet trained or capable of washing themselves. ${ }^{39}$

37. Henry L. Minton, “The Iowa Child Welfare Research Station and the 1940 Debate on Intelligence: Carrying on the Legacy of a Concerned Mother," Journal of the History of Behavioral Sciences 20 (1984), 167.

38. Cravens, Before Head Start, 175.

39. Harold M. Skeels, Beth L. Wellman, Ruth Updegraff, Harold M. Williams, and George D. Stoddard, eds., A Study of Environmental Stimulation: An Orphanage Preschool Project, University of Iowa Studies, vol. 15, no. 363 (1938), 10-11. 


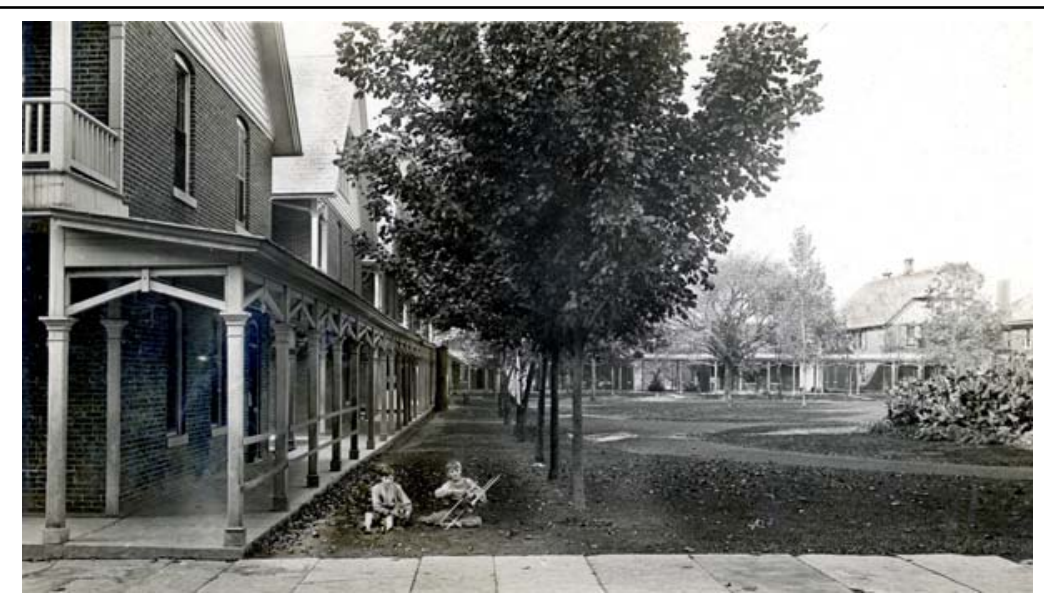

Two boys play in front of the boys' cottages at the Iowa Soldiers' Orphans' Home, probably in the 1920s or early 1930s. Photo from State Historical Society of Iowa, Iowa City.

In 1935, at the center of the ring of cottages, the ICWRS, with the help of state funding, built a preschool costing $\$ 7,280$ (about $\$ 115,000$ in today's dollars). For the next three years, the ICWRS tracked children grouped by age and IQ scores, monitoring the progress of those who attended the preschool and those who did not. All of the children had been at the orphanage for 18-21 months and ranged in age from 18 months to 5 years. The study was a small one of 46 children enrolled in the preschool and 44 whose daily routine remained unchanged. ${ }^{40}$ The researchers remained skeptical of what the IQ test truly tested but used it nonetheless because it was the commonly accepted standard of the era. They expected the IQs of those attending the preschool to rise precipitously.

Instead, over the three years of the study, they saw inconsistent and modest gains among children enrolled in the preschool. The real surprise was the effect of long residency at the orphanage on those in the control group. Instead of staying static, as expected, the effect "was a leveling one, tending to bring all children [regardless of initial IQ score] to high-grade feeble- 
mindedness or borderline classification" (IQ range of 70-79). The two children in the control group with the highest initial scores lost 28.5 points, and two others lost 43 and 37 points. ${ }^{41}$ The authors of the study concluded that the preschool's main effect was to prevent further harm to the children's scores and, presumably, their psychological and educational development. It was a nuanced difference-the difference between improving children's developmental potential and protecting them from an environment hazardous to that development.

The results strongly suggested the malleability of intelligence and raised questions about what the word even meant-and the ICWRS researchers had achieved those results by employing the same tool Lewis Terman had used to support the opposite position. Terman's IQ test was not the ICWRS researchers' only method of assessment, however; his IQ test and one not associated with Stanford or Terman produced similar results. Additional tests of language and vocabulary showed both groups lagging well behind children of similar ages in Iowa City. Even with the addition of the preschool, the children did not receive enough language stimulation, and they had little access to books and other means of promoting language development.

General information tests produced similar results when their results were compared to those of test-takers in the world outside the orphanage. Nevertheless, the preschool groupdespite its modest improvements-always did better than the control group when assessed using intelligence tests as well as other measures. One important area in which the preschool group improved most markedly was in social maturity - a "progressive capacity for looking after themselves" - which was important for placement with an adoptive family. In the area of motor skills (hopping, skipping, climbing ladders, jumping), the preschool children's scores approached those of Iowa City children. ${ }^{42}$ At the study's conclusion, the staff was convinced of the preschool's value even before they saw the report, so all of the children were enrolled in the preschool, playground equipment was added, and the child-to-adult ratio reduced.

41. Ibid., 45, 56 .

42. Ibid., 180-81. 
IN CONTRAST to their dismissive view of critics like Lippmann, the hereditarians took the work of Stoddard and the ICWRS as a direct threat. They feared that "environmentalists" would succeed in demonstrating the role of environmental factors in human development. Such a heretical notion would have consequences. Intelligence testing had reified as "natural" essentialist notions about race, gender, and social class. The research produced by the ICWRS was a threat not just to that idea but also to the entire social structure it supported.

For Terman and other adherents of a strict hereditarian view, if the IQ test did measure intelligence and if intelligence was fixed, the results at the Iowa Soldiers' Orphans' Home simply were not possible. Terman worked to ensure that psychologists and the public ignored or dismissed the ICWRS findings. On July 7, 1939, at his behest, Stanford University's School of Education convened a symposium before an audience of 1,200 teachers and school administrators with the goal of putting to rest questions about the relationship between genetics and environment in determining a person's intelligence. To address this complex question, Terman and his supporters were allotted an hour; Stoddard, upon arriving in Palo Alto, learned that he would have ten minutes to defend his claim that intelligence was not fixed. ${ }^{43}$

In his presentation, Terman dismissed the ICWRS studies that found that preschool attendance resulted in higher IQ scores. He reserved special ire for an ICWRS follow-up study on children from the orphanage who had been placed in foster and adoptive homes. Both preschool and control group children with relatively high IQs had been placed; those with lower IQs had not. After placement, individual children from both the preschool and control groups increased their IQ scores the longer they were with their foster or adoptive families, with children who had been in the preschool making more substantial gains. Their IQs eventually came to more closely resemble those of their foster or adoptive parents than of their birth mothers (little was known about the fathers). The children who remained in the orphanage did not make any gains by the end of the project. ${ }^{44}$

43. Stoddard, The Pursuit of Education, 56.

44. Skeels, et al., eds., Study of Environmental Stimulation, 56, 58. The study of adopted children would become a longitudinal study lasting 15 years, with the 
At the Palo Alto symposium, Terman responded to the claim that environment influenced individual intelligence by assailing the data, demanding additional proof, and asserting that others had not been able to replicate the results. In argument, nuance failed to hold Terman's interest. Using rhetoric as dichotomous as his science, he mischaracterized the Iowa results into an exaggerated inversion of his own, claiming (falsely) that the researchers believed they had "demonstrated the possibility of almost unlimited IQ control." 45 Stoddard responded by presenting the data from Iowa as well as other universities, to no avail. In his autobiography, he quoted the symposium's chairman as confessing after the symposium that "I held Stoddard while Terman beat him." Neutral observers found Terman rude and believed that he had "made a fool out of himself." 46

No complete copy exists of Stoddard's ten-minute response in Palo Alto, but the record does contain some revealing excerpts. Mulling over the twists of the debate over the previous years, Stoddard announced that he was not going to fuel Terman's arguments by offering statements Terman would then misrepresent. In unraveling the claims of hereditarians, he said, having followed "the devious course of many a colored yarn, I shall not

children tested at 2, 4, 7, and 14 years old. Begun by Howard Skeels, the report, when published in its final version in 1949 by Marie Skodak, became known simply as "Skodak and Skeels" and as "the most famous and most controversial adoption study in psychology's history." Charles M. Locurto, Sense and Nonsense about IQ: The Case for Uniqueness (New York, 1991), 37-38. Its implications found expression in public policy in John F. Kennedy's New Frontier, Lyndon Johnson's Great Society programs and War on Poverty, the 1984 Equal Opportunity Act, Job Corps, Vista, and Community Action Programs, including Head Start. Over the years, as with Terman's critique of the orphanage preschool and its related studies, Head Start, part of the ICWRS legacy, has had its efficacy questioned. Some studies find that the gains demonstrated by children upon completing the program disappear after two or three years in school. Head Start's defenders point out that it is a service project, not a research program (unlike the ICWRS studies, which blended the two). Each program is unique and not designed with program evaluation as a primary goal, so combining what are sometimes quite different programs obscures differences in design and effect while forgetting to treat children as individuals. A more important question: Even if post-Head Start gains disappear after the children enter school, what happens to those children in school?

45. Daily Iowan, 12/29/1939.

46. Stoddard, The Pursuit of Education, 58. 
undertake to supply the woof to anybody's warp." 47 Even so, the child, he said, is plastic; intelligence tests are imperfect and irrational. Many of the test questions relied on familiarity with cultural norms and thus their results measured cultural differences. They have value, said Stoddard, but more as measures of environmental influences than of intelligence. ${ }^{48}$ Terman, afterward, wrote to a friend that Stoddard was a "dangerous man." 49

Terman would fail in his efforts to prevent the ICWRS studies from gaining public attention, yet even when they did the ideas were often incorrectly portrayed as a question of nature versus nurture rather than emphasizing an interactive relationship between environment and intelligence, of nature and nurture working in concert. An article in early October of that year in the Salt Lake Tribune was one of many reflecting this common misinterpretation. Citing the Iowa studies, it encouraged parents to get their children tested. IQ could be raised, the article claimed, because environment had more to do with intelligence than heredity. The first assertion accurately reflected the Iowa findings, but the second was stretched even more by the declaration that "geniuses can be made as well as born" - a significant leap from Stoddard's koan-like equivocation that "the child can only be what he could have become." 50

Stoddard, in assessing the hereditarians and how they coopted Binet's test, wrote that Terman and others simply did not respect the qualifications Binet made about the limits of his test. A primary concern of Stoddard's was that IQ tests relied on the thinnest of evidence. The test used by Terman to identify genius in high school students consisted of the following: a vocabulary test requiring a mastery of only 13,500 words; a visualization test involving folding paper, cutting holes, and predicting how many would be revealed upon unfolding; repeating digits in forward and reverse order; explaining text that Stoddard described as "elementary"; and answering questions about how to measure pints of water.

47. Ibid.

48. Ibid., 59-60.

49. Minton, Lewis M. Terman, 195-97.

50. Stoddard, The Pursuit of Education, 59. 
In addition, Stoddard was confounded by the hereditarians' habit of protecting the test at all cost. Having asserted that the IQ test did measure intelligence, and that intelligence was fixed, they evaluated the results based on whether those results conformed to the expectation that a person tested repeatedly would consistently produce identical scores. When scores were inconsistent, Stoddard said, the hereditarians' were more concerned to protect the test's reputation than to understand the student.

The confusion is this: if we find some external physical "reason" for poor test performance, we tend to discount the testing; if the "reason" remains obscure, locked up in the internal mechanism of the organism, we tend to accept the results as bona fide. . . . Neither test constructor nor clinician hesitates to say that a child's brightness has remained static when the IQ is constant; when he finds the IQ inconstant, particularly if the change is radical, then what has changed is something other than brightness! ${ }^{51}$

IN THE LATTER STAGES of Terman's career, his views on intelligence reveal some inconsistencies. Biographers, as well as many textbooks on the history of psychology, quote Ernest R. Hilgard's 1957 obituary of Terman in which Hilgard implies that Terman eventually modified his hereditarian position on IQ and intelligence. In the obituary, Hilgard quotes a passage from Terman's 1932 autobiography: “the major differences between children of high and low IQ, and the major differences in the intelligence test scores of certain races, as Negroes and whites, will never be fully accounted for on the environmental hypothesis." In the margin of Terman's personal copy, notes Hilgard, Terman penciled in, "I am less sure of this now (1951)! And still less sure in 1955! - L. M. T." 52

At several points in his 1937 revision of the Stanford-Binet test, Terman's analysis became less adamant in tone and conclusions than it had been in previous publications. For example, he notes that the mean values of differences between correlations of IQ scores with social class are too small to be significant. ${ }^{53}$

51. Stoddard, The Meaning of Intelligence, 89.

52. Ernest R. Hilgard, “Lewis Madison Terman: 1877-1956," American Journal of Psychology 70 (1957), 478.

53. Minton, Lewis M. Terman, 152. 
Certainly, this sounds like someone retreating from a central tenet of biodeterminism - the notion that social class is determined by heredity. Such moments invite questions about what Terman truly believed and suggest someone in conflict over deeply entrenched ideas. Thus, sympathetic observers argue that Terman modified his previous views.

In his published writing, however, Terman never expressed the degree of doubt found in the margins of his writing. Minton argues that a desire to protect his professional reputation impeded his willingness to openly question his position. ${ }^{54}$ Supporting Minton's conclusion was Terman's reaction to the ICWRS's publication of A Study of Environmental Stimulation: An Orphanage Preschool Project. Even after the publication of Terman's more reserved 1937 revision of the Stanford-Binet test, he continued to attack - in print and in public and without reservation - the Iowa interactionists' findings on intelligence.

A letter from Terman student Florence Goodenough reflects the hereditarians' attitudes about the Iowa researchers. In the letter, sent to Leta Hollingworth, a researcher Terman respected despite views on intelligence less reliant on heredity than his own, Goodenough expressed her opinion of Beth Wellman. "The time had come," she wrote, "for letting the Iowa people know something about how the land lies." Terman, she wrote, believed that Wellman intentionally tried to deceive readers of her reports, while Goodenough believed that she had deceived herself. She compared Wellman to "a religious fanatic who hears the wings of angels in every rustle of the dishtowels on the family clothes line." 55

After the symposium in 1939, Terman successfully marginalized the ICWRS's interactionist position. He continued to target Stoddard and the ICWRS whenever possible, managing to halt the momentum for a national nursery school program that Stoddard had advocated for most of the decade. It advanced as far as a speech at the White House, then died. The economic realities of the Great Depression played a role, but

54. Minton, "The Iowa Child Welfare Research Station and the 1940 Debate on Intelligence, 160-76.

55. Minton, Lewis M. Terman, 161. 
Terman made its dismissal easier by arranging to have his symposium speech circulated among the right hands in official Washington. In language that does not sound like someone reconsidering his position, he would later boast of his success in "turning the tide" against Stoddard's wishes for "moron nursemaids." 56

While Terman believed that IQ tests demonstrated the insignificance of environmental factors, the Iowa researchers, led by Stoddard, advocated the opposite position, that IQ tests demonstrated the significance of environmental influence and should be used as indices of social change. ${ }^{57}$ (They would be, but not until the 1960s.58) The public and academic tides were with the Iowa researchers, and the shift in perceptions of intelligence in the ten years between 1928 and 1938 can be partly credited for growth in support for New Deal legislation. Throughout the period, the number of children in the workforce had reached its highest historical levels because of economic stress and Social Darwinist theories that validated variable treatment of children based on social rank. But by 1938, after many failed attempts, passage of the Fair Labor Standards Act mandated federal standards for child labor practices and signified critical changes in perceptions of a child's place in society.

The changing perceptions of childhood development also affected the relative emphasis on formal education and its availability. One of the many ways this was manifested was in levels of high school enrollment. Before 1920 only a small percentage of children attended public high schools; by 1930 half did; and ten years later enrollment rose to two-thirds. ${ }^{59}$

56. Cravens, Before Head Start, 201; Stoddard, The Pursuit of Education, 59-60; Minton, Lewis M. Terman, 195; L. M. Terman and M. A. Merrill, Measuring Intelligence: A Guide to the Administration of the New Revised Stanford-Binet Tests of Intelligence (Boston, 1937), 48-49.

57. Stoddard, The Meaning of Intelligence, 470-71.

58. Minton, Lewis M. Terman, 198.

59. Geraldine Jonçich Clifford, "A Sysiphean Task: Historical Perspectives on Writing and Reading Instruction," introduction to Anne Haas Dyson, Collaboration through Writing and Reading: Exploring Possibilities (Urbana, IL, 1989), 44; Lewis Terman, The Measurement of Intelligence: An Explanation of and Complete Guide for the Use of the Stanford Revision and Extension of the Binet-Simon Intelligence Scale (New York, 1916), 91-92. 
The mainstream psychological establishment had, from the outset, found Binet-derived scales "not sufficiently self-critical"; by the beginning of World War II, the hereditarian notions of Terman and others in the intelligence testing community had increasingly fallen out of favor. ${ }^{60}$ Complicating the question of what Terman truly believed, and raising the question as to whether the tenor of the debate between the two groups pushed both to take more extreme positions than they actually held, was Terman's own statement in the 1940 Yearbook of the National Society for the Study of Education that the environment could not be "regarded as a matter of small consequence." 61

STODDARD would leave Iowa in 1942 to become New York State's Commissioner of Education. A year later, reflecting on the debates over the meaning and testing of intelligence, Stoddard called fascination with the hereditarian idea of intelligence bad science that offered a false solution to society's ills. He argued that the belief in intelligence as determined solely by biology, easily tested for and quantified as a single number and offered as a nearly singular explanation for human behavior, invited too much confidence in our ability to engineer a better future through a narrow lens focused on genetics and the brain. In The Meaning of Intelligence, a nearly 500-page rebuttal to the hereditarians, Stoddard, referring to the cerebral cortex as "our luxury of luxuries," remarked,

It takes no frontal tumor to knock out the brain. The abscesses of fear, magic, and murderousness serve equally well and are more readily distributed. ... For the most deadly and universal mental afflictions, starting from the impact of man upon man, it is necessary to postulate healthy tissues, in order that the phobia may take hold. ... All the tumors the world has ever known have not been so destructive of human beings and human aspirations as singlepurpose concepts like witchcraft, divine right, original sin, heresy, racial superiority and might makes right. . . . Why is there such an ongoing interest in defining, measuring, and labeling racial characteristics? Very likely the doctrine of racial inferiority ... constitutes

60. Carson, The Measure of Merit, 181.

61. Minton, Lewis M. Terman, 168. 
a social need for millions of white persons who cannot otherwise escape the unpleasant outcomes of their own actions and attitudes. ${ }^{62}$

In 1945 Stoddard was hired as president of the University of Illinois, where he would gain a reputation, according to Charles Shadduck, a friend and professor in the English Department, of being generous and highly social but also someone who did not suffer fools. Stoddard himself would not have disagreed with such an assessment. He described himself as someone often absorbed within his own thoughts who could thus appear even deafer than he actually was. "Though hard-of-hearing at the best of times," he wrote, his abstraction "imparts an air of remoteness or indifference to the speech of others."

It can become a source of unintentional rudeness but, I think, not of malice. My inner satisfactions relate to this ambivalence. I cannot pretend to be a hail-fellow-well-met, a hearty, grinning slapper of backs. I am guilty of the cold eye and the dour look. If persons bore me, I probably show it, although a bore by definition is the last one to notice. On the other hand, I am apt to "take fire" and display an emotionally tinged response. At such times I become compulsively articulate. The hardest stance for me is to remain cool to what I regard as original and exciting, or, on the other hand, to what strikes me as stupid, corrupt, or malicious. My most intense pleasure is to be in touch with a warm creative person who represents what human nature is or could be. ${ }^{63}$

When Stoddard was hired, the Illinois Alumni News described him as "charming" and "highly-recommended." Reporting on Stoddard's forced resignation seven years later after he displeased the university's politically conservative board of trustees, Time magazine described Stoddard as hot-tempered, with a reputation among state legislators for being "anything but diplomatic." 64 A typical "Stoddard story" from his years at Illinois recounts his reaction to a state legislator announcing in the press that there were "fifty red communist pinkos at the university." Stoddard responded by sending the legislator a sheet of paper with blank lines numbered one to fifty along

62. Stoddard, The Meaning of Intelligence, 470-71.

63. Stoddard, The Pursuit of Education, 330-31.

64. "Education: The Final Arrow," Time, 3/8/1953. 
with a note asking him to please supply the names. Shadduck described the exchange as a "typical Stoddard response to dealing with a vicious idiot." 65

With the arrival of GIs home from World War II and the new GI Bill's support for them to attend college, the university's enrollment doubled in Stoddard's first year to more than 23,000. He oversaw a period of tremendous growth in the size and quality of the university, but after the election of a new, more politically conservative board of trustees, the outspoken and proudly liberal Stoddard became, in their view, an elitist easterner who wanted to create the "Harvard of the Midwest" and thus someone who should be regarded with suspicion. Once again, he was, in short, "a dangerous man."

He lasted for seven years, from 1946 to 1953. A year before his dismissal Stoddard had become embroiled in a public dispute with Andrew C. Ivy, the university's vice-president and a popular physiologist who had begun producing and popularizing Krebiozen, a drug that he claimed could cure cancer. It was derived from horse and cattle serum given to Ivy by two brothers in Argentina who never produced a powder testable by a third party. After a year of delays, Stoddard, relying on advisers including the American Medical Association, ordered Ivy to stop using university facilities to produce and administer the drug. For this, Stoddard was accused of infringing on academic freedom. His somewhat imperious nature in dealing with the state legislature was cited as another reason for his dismissal by the board of trustees who, led by former football star Red Grange, produced a 6-3 vote of no confidence. 66

Reports at the time and since noted the political and cultural forces behind the decision. Stoddard's politics were well-known, as was his association with UNESCO and his image as an internationalist, an identity that made some uncomfortable. Stoddard was well liked on campus, where he was seen as a "scholarpresident." He was a hero especially to the young faculty who, in many cases, had been recruited from out of state, an unpopu-

65. Charles Shadduck, interview by Katherine Corcoran, 10/23/1978, tape 1, box 2, University of Illinois Archives, University of Illinois Library, Urbana, IL. 66. "Education: The Final Arrow." 
lar move in the eyes of the legislature and board of trustees who feared the influence of "radicals." 67

Stoddard was right about Krebiozen, which was never demonstrated to offer an appreciable benefit ("horse piss" was one blunt description of the substance), although it did have numerous side effects. Ivy evaded criminal charges, but his reputation would remain that of a charlatan and media hound. Stoddard's reputation suffered from association with the scandal, and he had to defend himself in an 11-year court battle with Ivy, in which Stoddard was eventually exonerated. 68

The university apparently preferred to forget the Stoddard era. No buildings bear his name, nor are there memorials or book collections in his name in the library. Hundreds of portraits line hallways and rooms in the university's student union memorializing administrators, members of boards of trustees, professors, and famous alumni. So numerous and identical in size that they seem to blend into one identical image, they are the sort of paintings thousands pass without a glance, yet even among them Stoddard is conspicuously absent.

For someone who counseled General MacArthur on occupation strategies after World War II, helped found Parents magazine, and served on the board of UNESCO, among other duties, his forced resignation was a humiliation. His career continued as dean of the School of Education then chancellor and vicepresident at New York University, with interludes sponsored by the State Department to postwar South Korea, where he evaluated educational needs. In Iran, he advised the Shah on the creation of a College of Education in the University of Tehran, a plan that died with the Shah. Stoddard then played a longrunning role advocating the development of public television. A New York Times obituary noted his tenure at Illinois and the Krebiozen controversy but did not mention his stewardship of the Iowa Child Welfare Research Station or his debates with Lewis Terman over intelligence testing. ${ }^{69}$

67. Champaign-Urbana News-Gazette, 8/7/1983.

68. Stoddard, The Pursuit of Education, 344-46.

69. “George D. Stoddard Is Dead at 84," New York Times, 12/30/1981. 
It was at the University of Iowa, however, where he did some of his most important work as a defender of academic freedom the principle he was accused of subverting at Illinois - and as an advocate and defender of unpopular ideas at a time when public opinion favored the hereditarian position of biological determinism. His voice was not a solitary one, but for a critical period it was a persistent and high-profile voice defending research that delivered a deep psychological shock to prevailing views on intelligence and their relationship to ideas of a meritocracy. 